\title{
Strategy of Da'wah to Improve Muallaf's Religiousity in Dologuo Village, Bolaangmongondow Regency
}

\author{
Sahari $^{1}$, Edi Gunawan ${ }^{2 *} \&$ Murjani $^{3}$ \\ ${ }^{12}$ IAIN Manado, Indonesia \\ 3STAI Darul Ulum Kandangan, Indonesia \\ *edigunawan@iain-manado.ac.id
}

\begin{abstract}
This paper analyzes the religious-social activities done by the preachers as the strategy of da'wah for those who are converted to Islam or "muallaf" in Dologuo Village, Bolaangmongondow Regency. By employing qualitative research, this paper argues that the strategy of da'wah maintained by the preacher ("dai") has influenced to the improvement of religiosity of the "muallaf". This paper found that the da'i bas been able to implement the strategy of da'wah that is in line with the need of "muallaf". They established the religious circle or "pengajian", provide religious books as the reference for the muallaf and building the social cohesion among between the muallaf and the broader Muslim community. This religious commitment can be seen at their ritual, knowledge, and attitude. This study seeks to contribute to the formulation of proper strategy of da'wah to the muallaf.
\end{abstract}

Keyword: strategy of da'wah; commitment; religiosity; muallaf.

\begin{abstract}
ABSTRAK
Penelitian ini bertujuan untuk menganalisis aktivitas sosial keagamaan dan kemasyarakatan yang dijadikan sebagai sarana dan strategi dakwah oleh para da'i dan berimplikasi pada perubahan prilaku (komitmen religiusitas) muallaf di Desa Doloduo Kabupaten Bolaangmongondow. Penelitian ini menggunakan pendekatan deskriptifkualitatif. Hasil penelitian menunjukkan bahwa strategi yang digunakan da'i di Doloduo Bolaangmongondow menyesuaikan dengan kebutuhan muallaf, yaitu meliputi penguatan aspek akidah, ibadah dan muamalah. Selain itu, dakwah dilakukan melalui kelompok pengajian, memberikan buku-buku agama sebagai bacaan dan mempererat persaudaraan antara muallaf dengan muslim lainnya. Komitmen religiusitas muallaf secara umum sudah tampak bagus dilihat dari beberapa indikator yaitu; aspek keimanan, aspek ritual/ibadah, aspek penghayatan atau kedekatannya dengan Allah, aspek pengetahuan tentang ajaran pokok dalam Islam dan akhlak. Penelitian ini berimplikasi pada perumusan formulasi dakwah yang dilakukan terhadap muallaf.
\end{abstract}

Kata Kunci: strategi dakwah; komitmen; religiusitas; muallaf. 


\section{INTRODUCTION}

One of the objectives of da'wah is to maintain human's dignity by implementing the teaching of Islam. Al Qur'an indicates that the main objective of the human being creation is to be the "khalifa" on the earth (Seha, 2012). Dawah has been aimed to maintain the dignity of human being and thus the human being do not humiliate themselves by committing sins.

"Strategy" is "tactics" and "trick". According to "Kamus Besar Bahasa Indonesia", "strategy" is a well-prepared plan on certain activity to achieve certain objective. Meanwhile, the term "da'wah" means "the call, allurement, request," (Munawwir, 1984). "Strategy od da'wah" thus means a planning for certain activities to call and spread the teaching of Islam to the audiences. Da'wah is the implementation of faith in the daily and social life. According to Chairiawaty, da'wah is not only the normative understanding of the value of Islam, but also the understanding of social life and social environment of the object of da'wah (Chairiawaty \& Zakiah, 2020). Furthermore, da'wah also could be understood as the rhetoric and written activities to call the society to obey the teaching of Islam to gain the happiness in this life and hereafter (Priyanto, 2015).

Accordingly, da'wah contains two meanings: the call for obedience and goodness or the call for the opposite. Islam is the religion which commands its adherents (personal, community, or institution) to spread the teaching and values of Islam. Al-Quran has commanded the Muslim community both individual and community including religious elites to provide social services to all the human being without exception.

In this sense, it is the duty of Muslim community to provide guidance to the "muallaf"- the new-converted to Islam-whose faith still need improvement. Regardless of the motive of conversion, "muallaf" is the one to whom the Muslim community should pay their attention and guidance. Ultimately, it is the blessing ("hidayah") from Allah that people converted to Islam.

There are two main factors determining religious conversion. First, internal factor. People converted to Islam driven by the internal consciousness and choices. This type of muallaf understand the consequences of their conversion and will strongly hold their obedience and faith. Second, external factor. This is the case when someone converting to Islam due to the requirement of marriage administration or 
something forcing him/her to convert to Islam. This type of muallaf is reluctant in term of his/her religiosity. Their obedience to Islam will be depending on the external factor and the social environment.

When people converted to other religion, they might encounter mental, cultural, and social changes (Ministry of Religion Republic of Indonesia, 2012). As the consequences of their conversion, they should leave all things relate with his/her previous religion. The basic faith of Islam which consist of six pillars; believe in Allah, believe in the Angels, believe in the Holy Books, believe in the Prophets, believe in the Day of Judgement, and believe in the Destiny. These unique Islamic teaching differ from other religious teaching. Muallaf might experience difficulties to follow ritual in Islam. This difficulty might lead to phycological, social, and spiritual problem.

Therefore, Muslim community should help the muallaf to anticipate the cultural shock by guiding them gradually to the teaching of Islam. Muslim community also should care about their social environment. Da'i should guide the muallaf become a truly Muslim.

There are many cases of muallaf who face many difficulties when they converted to Islam. One of them is Aneke Mangahgantang who converted to Islam in 2001. She told that prior to decide to convert to Islam, she was struggling to make such decision. All her family is Christian, even her parents has been managing the church. Finally, Aneke decided to convert to Islam due to the requirement of marriage administration-her prospective husband is a Muslim. Initially, Anneke was still not convinced to conduct the teaching of Islam. Fortunately, her husband has been guiding her as she already fully committed to the teaching of Islam.

We should differentiate the strategy of da'wah when addressing the muallaf. We could not take the same strategy we we address the general Muslim community. It is because muallaf still need a gradual guidance on basic teaching of Islam. Mualla need to be guided systematically from theology (aqidab), law (syariah), and social relations (muamalab). We regard muallaf as a child when they learn Islam.

Muallaf needs an intensive guidance to understand the teaching of Islam as a whole (kaaffah) (Qurrotun A'yun dan Asrul Anan, 2019). This guidance is aimed to make muallaf can resolve their own daily religious issues. Regarding to the material guidance for the muallaf, we should deliver a moderate understanding of Islam to avoid misunderstanding of the teaching of Islam among the muallaf. The moderate understanding of Islam 
also can anticipate a hatred attitude of the muallaf to the other group both in internal Muslim community and other religion's adherent.

In the context of da'wah in North Sulawesi, it is important to implement a different strategy of da'wah to adapt with the local context and accommodate the interest of the local people. In the sense, this paper seeks to explore the strategy of da'wah implemented by da'i, teacher at religious school, and religious elite to improve the degree of religiosity of muallaf in Dolodua village, Bolaangmongondow Regency.

There are previous studies addressing the topic of the religiosity of the muallaf. Titian Hakiki and Rudi Cahyono (2015) describe the religiosity of adult muallaf particularly when they understand, practice, and maintain the teaching of Islam in the daily life. The two found that the way in which the adult muallaf maintain their religiosity is similar with the category of religious commitment formulated by Stark and Glock (1968).

Rasyidah (2017) studies strategy of da'wah among Muslim villagers in West Aceh. This study found that community-oriented da'wah is the effective way to deal with the villagers, particularly for children and the old generation. The pattern of da'wah employed in this community is structural media campaign and cultural-Sufism. One of the driving factors determine the effectiveness of structural da'wah is the Acehnese commitment to the implementation of sharia.

Casmini (2020) studies the strategy of da'wah for muallaf using institutional approach. Casmini choose the strategy of da'wah employed by Muhammadiyah and Aisyiah as the case study. This study found that Aisyah, the woman-wing organization of Muhammadiyah, manages the training for woman preacher (muballighaat) that handle the muallaf. Besides, the improvement program to strengthen their faith, psychological aspect, spiritual, and family and empowering their livelihood has been managed to make them survive and able in implementing the teaching of Islam.

The strategy of da'wah has not been only conducted in Indonesia. We also can find it in other countries, for instance, Malaysia. Malaysia has been paying great attention to the strategy of da'wah for the muallaf. Study by Mohammad, Abd. Majid, and Mohd. Natsir (2018), shows that the effective way to teach muallaf about Islam is by referring directly to al Quran, the example of Prophet Muhammad., and dialogue. This study has several practical suggestions for the alternative approach to the muallaf in Malaysia.

Amiranadira (2018) studies the strategy of da'wah to the muallaf in 
Kuching (Serawak, Malaysia). This study found that the geographical condition (rural and urban) determines the strategy of da'wah. To improve the understanding of muallaf to the teaching of Islam, "khitobah" has been the effective way, which is implemented through mastering language, routine assistance, and providing the material containing aqidah, syariah, and mu'amalah.

Malinda (2020) studies the strategy of da'wah woman preacher, Lilis Mulyani, who deal with the muallaf in Sabah, Malaysia. This study found that Lilis Mulyani employed da'wah bil lisan (rhetoric preaching), da'wah bil haal (practical preaching), and mujaadalab (dialectical dialogue) to improve muallaf's understanding to Islam. This study suggests the alternative way of preaching to the muallaf.

Focusing on the strategy of da'wah employed by teachers at religious school, ulama, and da'i, this study seeks to fill the gap of the previous research which did not address the strategy of da'wah to improve the religious commitment of muallaf in Doloduo village, Bolaangmongondow regency. This is a descriptive-qualitative research using a case study. This study employs purposive sampling to select the informants which fit with the research criteria. This study analyses the socio-religious activity of those who engage with the muallaf that impacted the religious behaviour and commitment of the muallaf di Doloduo village, Bolaangmongondow regency.

\section{RESULT AND DISCUSSION}

\section{Approach of Da'wah: Planning, Guidance, and Controlling}

The strategy of da'wah for the contemporary Muslim community should not only conducted by delivering the normative teaching of Islam, such as halal-haram, command, and prohibition, etc., but also an approach addressing the real socio-religious problem, improving the quality of life, social cohesion with others religious group, etc.

Strategy of da'wah as a set of activity is aimed to enlighten, develop, and empower Muslim community. Da'wah is not only introducing the teaching of Islam to the people, but also providing alternative way for problem solving. As such, da'wah should upgrade spiritually and psychologically human's dignity. To achieve such objective, we should employ a proper strategy and methodology of da'wah. A da'i should equipped themselves with knowledge and skills that can handle any 
problem in the rural and remote area.

Muallaf is people whose faith and heart needs guidance for his tendency to the teaching of Islam (At Tabari, 2001). Muallaf also can be defined as someone who already converted to Islam by saying syahadat, while his faith and conviction is not strong enough that they need assistance and guidance by the broader Muslim community to understand Islam (Hakiki and Cahyono, 2015). Muallaf derived from allafa-yuallifu-ta'lifanmuallifun-muallafun-allif-là ta'lif. It is found in several places in al Quran: Āli 'Imrān:103, al-Anfāl: 63, at-Taubah: 60, dan an-Nūr: 43 (Rahayu, 2019).

In the Encyclopedia of Islamic Law, muallaf is defined as people whose faith and heart are interested and inclined to Islam (Azizah, 2018; Rostandi, 1993). Religious conversion is defined as people's conversion from one religion to the other one driven by the internal or external factors (Darajat, 1976). Walter Houston Clark defined "religious conversion" as a spiritual growth determining the people's conviction to its own religion. On the other hand, the muallaf has been seen as less engaged with its own new religion after conversion in term of their understanding and obedience (Syarifuddin, 2003).

Quraish Shihab understands one of verses in Al Quran, fa allafa bayna quluubikum as "make your all heart as one entity." This indicates the Allah has made strong social cohesion among Muslim community based on faith and affection. When Muslim community already united, every problem will be resolved. Muslim community is just like one human body; when one part felt pain, other part will sense the same pain. Therefore, when someone become muallaf, he or she has strong bond with other Muslim community. They joined the big family of Muslim ummah (Shihab, 2009).

There are 24 muallaf living in Doloduo village, Bolaangmongondow regency. The background of this religious conversion was marriage administrative requirements. This fact indicates that those muallaf should get assistance to strengthen their understanding toward the teaching of Islam and their social integration to the Muslim community as well (Bonde, 2021). The headman of Doloduo village said that there were many cases where muallaf did conversion back to their previous religion when they encounter conflict with his partner. Therefore, we need to strengthen their religious commitment.

All this time, there were several activities conducted by da'i and local religious figure to provide guidance for the muallaf. Unfortunately, 
those activities were not effective and impactful (Sanen, n.d.). According to one of informant, there are three main steps to gibe guidance for the muallaf in Doloduo village.

First, planning to decide the schedule for learning class for the muallaf. Usually, the da'i made an agreement with the muallaf on the schedule of learning and assistance. Besides, da'i also can take advantage of general gathering like arisan to deliver religious material for the muallaf. Arisan has been commonly practiced by the Indonesian society in which people gather routinely and it is a great chance for da'i to deliver religious teaching of Islam. Religious guidance also can be conducted through majelis taklim or religious circle in masjid. Apart from these, the muallaf can invite or come to the da'i to get assistance and guidance on the teaching of Islam privately.

Second, implementation. Da'i conducts the assistance and guidance program base the schedule. They deliver the material such as aqidah, ibadah, akblaq, and reciting al-Qur'an, etc. The da'i also encourage the muallaf to build and maintain a good relationship with other people. This good relationship hopefully will strengthen their internal faith. To maintaid the muallaf religiosity, the da'i teach them to maintain a good relationship with other Muslim fellows, including participating ith religious activities, such as the celebration of the birth of Prophet Muhammad (maulid), nuzuulul qur an, etc (Mubarok, et.al, 2018). Besides, the muallaf also encouraged to intensify their engagement with al Qur'an by reciting and understanding its meaning (Sanusi, 1994). To support the social integration of the muallaf to the Muslim society, th da'i should remind them to perform shalat, to attend religious events, pengajian, and to participate in social activities. Social interaction will lead to the social integration and social cohesion.

Third, togetherness. Social cohesion will maintain the muallaf's conviction to Islam. The muallaf's faith could also improve by the social cohesion and togetherness. The da'i should not only provide religious material. Togetherness could be maintained by empathy, social awareness, and participatory activities. Social integration would avoid the muallaf from social exclusion within Muslim community and beyond. Interview with da'i in Doloduo village shows that they implemented dialogue with the muallaf. Mujaadalah approach was conducted as a space for an open and engaged dialogue addressing internal and family issue of the muallaf. This kind of assistance implemented intensively to improve the muallaf commitment and conviction to Islam. There is basic material should be delivered to the 
muallaf, that is figh, including ablution, shalat, and the meaning of each ritual in Islam. The muallaf might be think that there is no difference between ablution and the general cleansing activity.

Muallaf in Doloduo village surely need a specific guidance, particularly in understanding and practicing the teaching of Islam (Syarifah, 2007). Therefore, da'i should prepare an effective way to provide guidance and assistance for the muallaf. They also should consider several things, such as the material, the objective, the method, and the evaluation of such program. Planning of da'wah targeting muallaf should be formulated through clear objective, so the muallaf can feel the beauty of Islam. The role of da'i has been important in assisting for the muallaf with an effective, efficient, and qualified guidance.

Beside of theology and fiqh, the assistance program for the muallaf should start with learning to recite al-Qur an properly. According the da'i, there are some methods regarding to learning to recite al Qur`an, for instance, using white board to teach and write the Arabic followed by Indonesian language. (1) Basic understanding to the teaching of Islam. Every muallaf should understand the five pillars of Islam dan the six pillars of believe. This kind of material delivered by da'i through da'wah billisaan (lecture) directly to the muallaf. Besides, the muallaf is instructed to read some of book references; (2) Skill to recite al-Quran and understanding its meanings. Every muallaf should be trained on how to recite al-Qur'an properly and understand its meaning under the guidance of the da'i; (3) Reading book reference. Da'i encourage muallaf to read many books dealing with the Islamic teaching, history, ritual, etc. Unfortunately, the muallaf did not easy access to such references. Nowadays, they can access such material directly from online sources (4) Maintaining social cohesion (ukhuwah islamiyyah) between muallaf and the broader Muslim community. Da'i explained to the muallaf on the danger of misunderstanding to the Islamic teachings. They also insisted that muallaf should not be absent in performing daily prayer dan his jobs. The muallaf should have a balanced life.

By examining the implementation of da'wah to the muallaf in Doloduo village, we could say that da'wah should not only addressing the issue of theology (aqidah), law (fiqh), and social interaction (mu'amalab), but also addressing the contemporary problem and offering solution for such problem, such as poverty, parenting, psychological well-being, etc.

Da'wah should not only implemented by lecturing, but also through 
providing good example and empowering people. Da'wah should be implemented through wisdom which is suitable with the need of target of da'wah as exemplified by Prophet Muhammad (Hafidhuddin, 2003).

Da'wah is the call to Allah by implementing a conducive environment for every Muslim to perform their obedience in every aspect of life. Prophet Muhammad has exemplified a strategy of da'wah which is aimed to empower the Muslim community (Safei, 2002). To achieve the objective of da'wah, da'i should formulated the strategy od da'wah. There are three strategies of da'wah which can be implemented by da'i. (1) Tadbir. Tadbir is establishing a strong and prosper society by formulating the policy, planning, implementation, monitoring, and evaluation; (2) Irsyad. Irsyad contains two things; counseling and guidance to provide solution dealing with many problems experienced by muallaf; (3) Tabligh and Ta'lim. Tabligh and Ta'lim implemented by delivering material on Islamic teaching to improve the muallaf knowledge and understanding; (4) Tathwir. Tathwir is implemented through empowering economic aspect of muallaf, including culture, health, education, etc. (Aripudin and Sambas, 2007).

Those methods should be implemented consistently and by the participation of da' $i$ as the center agent of da'wah. The ideal da' $i$ is not only Muslim who has spirit tanha 'anil fahsyaa wal munkar and ballighun 'anni walau ayah, but also equipped by the competence and skills to deal with the problem in the field of da'wah. Otherwise, it is difficult to achieve the objective of da'wah.

The incompetence of da'i in addressing the everyday problem of muallaf will cause to the muallaf confusion with the Islamic teaching. This situation probably will make the muallaf turn to their previous religion when they encounter private problem, such internal conflict in their household (Bonde, 2021)

"There are many cases in which people did religious conversion due to marriage administration requirement and did conversion to their previous religion when they experience household conflict with their wife/husband."

The other factor determining the religious conversion to previous religion is the internal faith of the muallaf. While they did not understand the teaching of Islam yet, as the result, their faith had not been improved. As told by the muallaf di Doloduo village, initially they convert to Islam not because they really understand and believe in the teaching of Islam (internally driven). They convert to Islam because they will marry with their 
prospective husband/wife. When they divorced with her partner, they convert again to their previous religion.

Yanto, one of male muallaf in Doloduo, told that he converted to Islam in December 2019. He said,

"I converted to Islam because I was planning to marry a woman

Muslim. Her parent asked me to convert to Islam if I wanted to marry her."

This is common cases in Doloduo villages. The muallaf did not convert to Islam voluntarily. They were being forced by the external factor, such their prospective husband/wife parent. It was not religious conviction which drive the muallaf convert to Islam. It was administrative marriage requirement which force people to convert (external factor). Externally driven religious conversion is not as strong as internally driven religious conversion. People who convert to Islam determined by external factor, in this case is administration marriage requirement, has been reluctant to change his or her conviction when there is a changing from external factor.

The other challenge faced by the muallaf is his weak commitment to perform any ritual in Islam, such as daily prayer, fasting in Ramadhan, paying zakat, and pilgrimage. It is difficult for the muallaf to follow such ritual when his commitment is quite low and there is no one who are guiding her or him.

The interview with the sample of muallaf shows that muallaf faced different problem in their start being of Muslim. Some of them feel hard to perform prayer (shalat) five times in one day. However, they are not feeling as hard as performing prayer when they supposed to do fasting during Ramadhan, paying zakat or other social interaction with other Muslim fellows. Some of muallaf already understood the teaching of Islam, although some of them did not understand it comprehensively.

In some cases, some of muallafs in Doloduo only follow their wife or husband religious practices. If their wife or husband is obedient to the teaching of Islam, the muallaf will be as obedient as their partner. This fact shows the importance of spouse in maintaining religious obedience. It is also important to maintain the role of da'i and religious figure to provide counceling and guidance for the muallaf in improving their knowledge about Islam and in dealing with their daily problems.

While the need for guidance of muallaf is crucial, the number of da' $i$ who can provide such program is limited. This is serious problem. The existing da'i doing their duty in Doloduo village need to be improved in 
term of their quality, skills, competence, etc.

On the other hand, the status of muallaf always be seen as the second or third class in the rural society. Muslim community tend to neglect their existence. We need to regard them as the special segment of the society who need more attention and guidance to make them as the productive and inclusive people.

\section{Religiousity of the Muallaf: Iman, Islam, Ihsan, Ilm, and 'Amal}

Muallaf's religious commitment can be measured from their understanding to the teaching of Islam, their daily religious performance, and their effort to enhance and maintain their obedience (Hakiki dan Cahyono, 2015). Commitment means the seriousness and sincerity to do something consistently. It binds someone emotionally and intellectually to do something (Imaddudin, 2008).

According to ethical perspective, commitment related with the willingness, persistency, and sincerity to be a better person. Someone who has commitment will make decision from their own side and stick on that decision (Lubis and Jaya, 2019; Kartono, 2017). Commitment is the way to maintain our principle, including principle to adhere to one single religion and or to defend it. As a Muslim who committed to Islam, a muallaf consistently obeys the Islamic teaching both the teaching of the relationship with Allah (bablum minallaah) and the teaching of the relationship with other human being (bablum minannaas).

Commitment implies someone's responsibility to something outside themselves. We can see someone's commitment through his or her sincerity to do the obligation. Commitment is an agreement between two sides. Commitment implies ill, sincerity, responsibility, and attachment. When people have committed to Islam, they should not only understand and practice the ritual, but also practicing a good attitude (akblaq al kariimah) in their daily life.

Our commitment to Islamic values will be resulted in our attitude and behavior. Muslim with good behavior and good attitude has shown their strong commitment to Islamic values. All religion surely commanded goodness to their adherents. Therefore, a religion's adherent with high commitment to their religion will maintain a good behavior and attitude based on their religious teaching (Ferdianti, Ulfia, and Farid, 2013). Commitment to religion will drive someone to internalize those religious values in their daily life. It also will influence the transformation of Islamic 
values in social interaction. This is indicated through the improvement of knowledge, faith, and consistency to perform ritual and religious experiences (Rustandi, 2020). When people committed to their believe, they will implement the religious teaching in daily life, for instance, helping other people, giving the poor, spread peace, etc. On the contrary, people who has poor commitment to their religion will not fully practice the religious teaching.

Islam is a religion which contains three aspects; as a system of believe, a set of teaching and values, and as a comprehensive regulation (Mayondhika, 2012). However, it is possible for a Muslim to not refer to Islam in their daily life. In the sense, there are five dimensions of commitment in Islam; Iman, Islam, Ibsan, Ilm, and 'Amal (Glock, 1968).

First, Iman means believe and faith which has six pillars as mentioned in the previous part. Second, Islam (ritual dimension) comprises performing prayer, including performing shalat at mosque, attending pengajian, etc. Third, Ibsan implies the internal activities such as considering the existence of Allah, being grateful (syukur), surrender (tawakkal), etc. Fourth, 'Ilm or knowledge of religious teachings. Fifth, 'Amal is Muslim daily activities within the broader society (Mayondhika, 2012).

Based on these five indicators of religious commitment, this paper examined religious commitment of muallaf in Doloduo. A muallaf who has been converting to Islam since 2012 due to marriage administrative requirement said that,

I have married three times. I have divorced in my first and second marriage. However, I still adhere to Islam, because I strongly convinced with Islam and feel comfort with Muslim community. There, my marriage problem did not affect to my religious conviction."

Regarding to practicing the teaching of Islam, she acknowledges that a true Muslim should realize the consequences of their decision by implementing the teaching of Islam without exception, for instance, prayer. She said,

Initially, it is difficult for me to perform prayer five times in one day. I was fortunate that my husband guided me to perform prayer consistently. He teaches me to have an intention (niyyat) to practice the teaching of Islam. Alhamdulillah, now I am eager to perform prayer both in home and mosques".

Menawhile, a male muallaf who has been converting to Islam due to 
marriage requirement said that syahadah is the principle he must keep in his entire life. He also said that in the beginning, his family did not accept his conversion. It was a difficult part in his religious journey. He also told us that it is impossible to convert to his previous religion because he already feels comfort with Islam.

In fact, not all muallaf can practice all the teaching of Islam properly. One of muallaf said that he still learns how to perform shalat, because he did not remember all the text in shalat, and he still feels shy to go to the mosque. However, he still performs shalat under the guidance from his wife. He realized that being a Muslim means that he must follow all the teaching of Islam, including performing shalat and doing fasting (shaum).

The other male muallaf who converted to Islam because of following his wife's religion said that after he learn about Islam, his conviction is stronger. He strongly wanted to die as a Muslim. He then called his mother to convert to Islam. He added that even though he was new to Islam, he was enthusiastic to practice the teaching of Islam and prior to his marriage, he is already interested with Islam.

The other female muallaf, Aneke Mangahgantang, said that practicing the prayer (shalat) has been her priority after he decided to convert to Islam. To him, shalat is the special interaction between her and Allah. When she performs shalat she felt comfort amid many problems she faced. Shalat has been healing her psychological problems.

According to the informants, we can conclude that the sample of muallaf have high religious commitment to Islam. They were enthusiastic to stick on Islam even they wanted to die as a Muslim. Besides, their religious commitment also drives them to call their relatives to convert to Islam. On the other hand, the muallaf has different level of religious knowledge. some of them already know the basic knowledge of Islam, while the rest still do not really know and understand it. For instance, some of muallaf still cannot perform shalat properly, including its recitation whereas shalat is the most important ritual in Islam.

Therefore, the role of religious figure, da'i, and teacher has been decisive to improve muallaf's knowledge of Islam. If they do not play their role effectively, the muallaf will not get a good assistance and guidance to be a true Muslim. Being a good Muslim is not only by the oral acknowledgement, but we also need to prove it with good deeds, that is believing in Allah, practicing the teaching of Islam, and maintaining a good attitude (akhlaq al kariimah). 
The teaching of Islam contains two general types; those which relates with Allah (hablum minallah) and those which relates with human being (hablum minannaas). These two types have one direction to devote our life for Allah by maintaining good relationship with human being. The faith could be achieved by performing the ritual and a good relationship in daily life. Our believe to the truth of Islam will influence our faith. In Islam, there six believes, that are believing in Allah, the Angels, the Prophets, the Holy Books, the Day of Judgement, and the Destiny.

Aqidah or theology is a field of Islamic teaching that contains the knowledge about Allah. It is obligatory for every Muslim mastering this field before mastering other field in Islam (Muhammad Saltut, 1994). Every Muslim must believe in Allah without any doubts (Fauzan, 2012).

Aqidah is the fundamental aspect in Islam. The core aspect in 'aqidah is believing in Allah by understanding Its Beautiful Name and Its Attributes. A true and strong 'aqidah will impacted the whole life of a Muslim. Meanwhile, ibadab is the evidence of Muslim's obedience to Allah. Ibadab enables connection between Muslim and Allah, the Creator of the universe. Al-Quran told, "Surely, my prayer, and all my (other) acts and forms of devotion and worship, and my living and my dying are for God alone, the Lord of the universe." (Al An'am: 162). There are many people claiming as a Muslim just because their parents are Muslim or living in Muslim community. However, their faith and attitude do not reflect a true Muslim.

As a true Muslim, muallaf should maintain good relationship with other Muslim fellows or ukhuwah islamiyyah. This term always understood as solidarity within Muslim community_as argued by al Qudhat (1994), yet it is better to understand it as "an solidarity based on Islamic values" (Shihab, 2014). Therefore, the brotherhood of Muslim is not limited within Muslim community, but also Muslim solidarity with other religion's adherents.

As a solidarity within Muslim community, ukbuwah islamiyah is maintained based on the common faith and believe. On the contrary, as a solidarity based on Islamic values, ukhuwah islamiyah established on the humanity as the same creation of Allah.

In the sense of Islamic teaching, ukhuwah Islamiyyah is defined as social relationship within Muslim community. We also can extent the context as the social relationship between Muslim community and the broader society. Social relations within Muslim community based on the 
common faith will contains many similarities than social relations with other religious community.

According to Quraish Shihab (2009), ukhuwah islamiyyah also implies the inter-religious solidarity, for instance, between Muslim and Christian community. Therefore, ukhuwah islamiyyah does not only means the solidarity within Muslim community. In line with Quraish Shihab's interpretation, Muslim community should maintain good relationship with other religious groups.

Meanwhile, da'i understands the concept of ukhuwah as something which does not relates with certain religion, ethnic, or race. For them, the main thing in social relations is good deeds, respect, and mutual understanding. However, not all da'i shared this understanding. Some of them still understand ukhuwah is the solidarity only among Muslims.

\section{CONCLUSION}

Da'i and religious figure in Doloduo, Bolaangmongondow employ common strategy to improve muallaf's religious commitment. This kind of strategy is oriented to improve knowledge and understanding of muallaf on Islamic teaching, including 'aqidah, ibadah, and mu'amalah. They also employs those strategy by providing religious books as muallaf references. This is also to establish social cohesion between muallaf. Da'i in Doloduo village did not attempt to make development and empowerment program for the muallaf.

The level of religious commitment of muallaf is quite good that we could see it from several indicators or aspect; aspect of faith ('aqidab) including believing in Allah, aspect ritual (ibadah) including paying zakaat, performing shalat, fasting during Ramadhan; aspect of ihsan as internal activities; aspect of 'ilm including the basic knowledge of Islam; aspect of akblaq including muallaf attitude and behavior in daily life as the result of faith. This study found that muallaf has acknowledged that they felt comfort after converting to Islam due to the kindness of Muslim community which is in contradiction with their perception before converting to Islam.

Regarding to the neglected muallaf di Doloduo, the local government-Ministry of Religious Affairs should pay more attention to them by providing guidance and assistance due to the limited number of well-trained da'i and religious figure in such area. This is to strengthen their 
religious commitment and da'wah program is not only implemented by delivering religious sermons and material of Islamic teaching, but also by improving knowledge, ritual, and religious experiences. The concept of ukhuwah islamiyah can be a central foundation for the muallaf to keep their faith and commitment to Islam and Muslim community and Da'wah program will be playing as the social transformation of the society.

\section{REFERENCES}

Al-Qudhat, M. (1994). Mabda'ul Ukbuwah fil Islam, terj. Fathur Subardi, Prinsip Ukbuwab dalam Islam. Solo: Hazanah Ilmu.

Amiranadira, N. (2018). Strategy of Khithabah in Dealing with Converts to Islam in Sarawak Malaysia, Jurnal Ilmu Dakwah: Academic Journal for Homiletic Studies, 12(2), 318-336. 10.15575/idajhs.v12i1.7470.

Aț-Ṭabarī, I. J. (2001). Tafsìr aț-T abarì. Juz 11: Ḥuqūq aṭ-Ṭaba' Maḥūẓah.

A'yun, Q., \& Anan, A. (2019). Penanaman Nilai-Nilai Pendidikan Agama Islam Pada muallaf persatuan islam tionghoa Indonesia Surabaya Jawa Timur (Studi Kasus pada Muallaf Persatuan Tionghoa Indonesia), Jurnal Mu'alim, 1(1), 19-32. https://www.jurnal.yudharta.ac.id/v2/index.php/muallim/article/v iew/1351.

Azizah, R. N. (2018). Sikap Keberagaman Muallaf Di Kabupaten Banyumas (Tesis). IAIN Purwokerto.

Casmini. (2020). Analysis of Muallaf 'Aisyiyah Da'wah Strategy, Jurnal Imu Dakwah: Academic Journal for Homiletic Studies, 14(1), 151-166. DOI: 10.15575/idajhs.v14i1.9238.

Chairiawaty \& Zakiah, K. (2020). Identitas Branding sebagai Strategi Dakwah: Islami Etika bisnis, Jurnal Ilmu Dakwah: Academic Journal for Homiletic Studies, 14(2), 259-274. DOI :10.15575/idajhs.v14i2.10595.

Darajat, Z. (1976). Ilmu Jiwa Agama. Jakarta: Bulan Bintang.

Ferdianti, E., Ulfiah., Nurdin, F. S. (2013). Hubungan Antara Komitmen Beragama Dengan Perilaku Prososial Pada Mahasiswa Fakultas Psikologi, Psymphatic: Jurnal Ilmiah Psikologi, 6(2), 871-885. DOI: https://doi.org/10.15575/psy.v6i2.2205.

Fauzan, S. I. (2012). Penejelasan Ringkas Matan al-Aqidah ath-Thahawiyah, Aqidah Ablussunnah wal-Jama'ah. Jakarta: Pustaka Sahifa.

Hafidhuddin, D. (2003). Islam Aplikatif (Cet. 1). Jakarta: Gema Insani.

Hakiki, T., \& Cahyono, R. (2015). Komitmen Beragama pada Muallaf 
(Studi Kasus pada Muallaf Usia Dewasa), Jurnal Psikologi Klinis Dan Kesehatan Mental, 4(2), 20-28. bttps://kbbi.web.id/strategi. (2021).

Imaddudin, A. (2008). Program Bimbingan dan Konseling Untuk Mengembangkan Komitmen Belajar Siswa Sekolah Menegah. FIP Universitas Pendidikan Indonesia.

Kartono, S. (2017). Crisis To Win Revolution. Jakarta: TransMedia Pustaka.

Kementrian Agama Republik Indonesia. (2012). Materi Bimbingan Agama

Pada Muslim Pemula (MUALLAF). Direktorat Jendral Bimbingan

Masyarakat Islam Direktorat Penerangan Agama Islam.

Lubis, H. M. J., \& Jaya, I. (2019). Komitmen Membangun Pendidikan. Medan: CV Widaya Puspa.

Malinda, N. A. (2020). Pola Dakwah Lilis Mulyani terhadap Muallaf di Sabah Malaysia, ANIDA (Aktualisasi Nuansa Ilmu Dakwah), 20(2), 146-164. DOI: https://doi.org/10.15575/anida.v20i2.8961.

Mayondhika, A. (2012). Hubungan Komitmen Beragama Dan Kesediaan Berkorban Untuk Agama. Depok, Universitas Indonesia.

Mohammad, N., Abd. Majid, M., \& Mohd Nasir, B. (2018). Pendekatan Dakwah dalam Kaedah Pengajaran Kepada Mualaf, Wardah, 19(1), 117. DOI https://doi.org/10.19109/wardah.v19i01.2427.

Mubarok, A. N. S. H., Rafsadie, D. A. K. I., \& Bagir, I. A.-F. Z. A. (2018). Agama, Kerukunan, dan Binadamai di Indonesia, Pusat Studi Agama dan Demokrasi (PUSAD) Yayasan Wakaf Paramadina Bekerja, 53(9).

Munawwir, A. W. (1984). Al-Munawwir: Kamus Arab-Indonesia. Surabaya: Pustaka Progresif.

Priyanto, E. (2015). Dakwah dan Kesalehan Sosial: Kiprah Dakwah Roostien Ilyas UIN Syarif Hidayatullah.

Rahayu, S. U. (2019). Muallaf dalam Perspektif Alquran, Al-I'jaz: Jurnal Kewabyuan Islam, 5(2), 92-115. DOI : 10.30821/al-i'jaz.v5i2.5789.

Rostandi, A. (1993). Ensiklopedia Dasar Islam. Jakarta: PT. Pradaya Paramita.

Rustandi, R. (2020). Dakwah Komunitas di Pedesaan dalam Perspektif Psikologi Komunikasi, Irsyad: Jurnal Bimbingan, Penyuluban, Konseling dan Psikoterapi Islam, 8(3), 301-322. DOI 10.15575/irsyad.v8i3.2009.

Safei, A. M. dan Muhyiddin, A. (2002). Metode Pengembangan Dakwah. Bandung: Pustaka Setia.

Saltut, S. M. (1994). Aqidah dan Syariah Islam (diterjemahkan oleh Fahruddin). Jakarta: Bumi Aksara.

Sanusi, S. M. (1994). Pemikiran-pemikiran Taubid, disalin oleh Asywadie Syukur. 
Surabaya: Bina Ilmu.

Seha, S. (2012). Paradigma Dakwah; Menata Ulang Penerapan Dakwah di Indonesia. Makassar: Alauddin University Press.

Shihab, M. Q. (2014). Birrul Walidain: Wawasan Al-Qur" an tentang Berbakti kepada Ibu Bapak. Jakarta: Lentera Hati.

Shihab, M. Q. (2009). Tafsir al-Mishbah: Vol. II. Jakarta: Lentera Hati.

Supriadi. (2018). Problematika muallaf dalam melaksanakan ajaran agama islam desa tumbang runen kecamatan kamping kabupaten katingan, Jurnal Hadaratul Madaniyah, 5(1), 41-44. DOI: https://doi.org/10.33084/jhm.v5i1.162.

Syarifah, H. (2007). Pendidikan Agama Islam Bagi Muallaf Di Pesantren Pembinaan Muallaf Yayasan An-Naba Center Indonesia. UIN Syarif Hidanatullah Jakarta.

Syarifuddin, A. (2003). Garis-Garis Besar Fiqih. Jakarta: Prenada Media Group. 